\title{
CARBON ISOTOPIC COMPOSITION OF LLANDOVERY ROCKS (EAST BALTIC SILURIAN) WITH ENVIRONMENTAL INTERPRETATION
}

\author{
Dimitri KALJO and Tõnu MARTMA
}

Institute of Geology, Tallinn Technical University, Estonia pst. 7, 10143 Tallinn, Estonia; kaljo@gi.ee

Received 31 July 2000, in revised form 24 October 2000

\begin{abstract}
Carbon isotope data from six borehole sections of Estonia and West Latvia are presented and analysed against different geological and palaeontological phenomena in order to understand possible reasons for shifts in $\delta^{13} \mathrm{C}$ values. Four most important carbon isotopic events are established in the Llandovery (from bottom): (1) a negative shift $(-0.5$ to $-1.5 \%$ o) in the Coronograptus cyphus Zone (in the Pusku Beds), (2) a positive excursion ( +3.0 to $+4.0 \%$ ) in the Demirastrites triangulatus Zone (Ikla Member), (3) a negative excursion $(-1.3$ to $-1.4 \%$ ) in the Stimulograptus sedgwickii Zone (Rumba Formation), (4) a small positive shift at the beginning of the Velise Formation in the Spirograptus guerichi-Streptograptus crispus Zone. The positive excursions seem to correspond to certain glacial events, negative ones to humid climatic episodes with rising sea level. In the case of the Rumba Formation the influence of carbon with low $\delta^{13} \mathrm{C}$ released due to volcanic activity in the late Aeronian is suggested. The background carbon isotope values are relatively stable during the Llandovery, showing some changes in correlation with facies and climate controlled stratigraphical units.
\end{abstract}

Key words: carbon isotopes, Llandovery, East Baltic, glaciations, facies changes, climates.

\section{INTRODUCTION}

The stable isotope composition of upper Ordovician and Silurian carbonates has been extensively studied during the last decade. Many of the projects aim mainly at understanding the causes of the Hirnantian, early and late Wenlock, and middle Ludlow environmental and biotic events. In some papers also stratigraphical and other aspects are discussed (e.g. Wenzel \& Joachimski 1996; 
Bickert et al. 1997; Marshall et al. 1997; Kaljo et al. 1998; Marshall \& Brenchley 1998; Kump et al. 1999). The Llandovery embraces a considerable time-span of $14 \mathrm{Ma}(429-443 \mathrm{Ma})$ between the latest Ordovician and earliest Wenlock, but stable isotopes have been less studied. This period deserves more serious attention due to important processes and events observed in the early Silurian environment.

First of all, the Llandovery could be considered as a time of recovery from the latest Ordovician glaciation, accompanied by sea level lowstand, mass extinction, and diversity low of biota. Climatically, the early Silurian belongs to a long greenhouse period (Fischer 1984) interrupted by three glaciation episodes as reported from South America (Caputo 1998). These interruptions were probably analogous to the well-studied Hirnantian short-term glaciation (Brenchley et al. 1994), but of lower rank, as might be deduced from their smaller environmental (sensu lato) after-effects. According to modern reconstructions of early Palaeozoic plate positions, Baltica moved from the temperate belt in the Middle Ordovician to the near-equatorial position at the end of the Ordovician and to the equatorial position by the Wenlock (Torsvik et al. 1996). Climatic consequences of the movement are obvious for Baltica, but not so clear globally. According to Wilde et al. (1991), the Llandovery was cooler than the late Ordovician (fall from about 140 to $130 \%$ compared to modern temperature values, the global average of which is about $15^{\circ} \mathrm{C}$ ). At the same time, the temperature curve compiled by Frakes (1979, cited in Morrow et al. 1995) shows steady warming beginning at the end of the Hirnantian glaciation episode, while the level of modern values was reached only in the middle of the Silurian. Also contents of atmospheric carbon dioxide and oxygen were lower in the Llandovery than during previous or following times, though actual values calculated by different authors may vary (Wilde et al. 1991). Regardless of the difference noted above, these data are concordant in general, and it would be most important to obtain a more detailed pattern of climatic changes.

After the end-Ordovician lowstand, sea level was clearly rising through the whole Llandovery, but with several lowerings. Johnson (1996) suggested four eustatic highstands with maxima in the late Rhuddanian, late Aeronian, early and late Telychian. From the East Baltic point of view, a conspicuous middle to early late Aeronian regression maximum should be mentioned. This event has been correlated (Einasto, pers. comm. 1998) with the Panuara Hiatus in Australia (Jell \& Talent 1989), and as such it seems to be a true eustatic event. However, very often local geological processes modify the global trend to a certain extent, making a local sea level curve and especially levels of maxima and minima different from the standard one. Such differences are seen also in Baltic sections. It has been shown that Llandovery sea level lows could be relatively well correlated with the three glaciation episodes mentioned (Caputo 1998; Kaljo et al. 1998). 
The biotic changes during the Llandovery consisted mainly in recovery and diversification. The period began with a low-diversity phase (mainly Rhuddanian) followed by a diversity rise, e.g. pelagic-planktic graptolites reached the maximum in the Aeronian, nektobenthic conodonts and planktic acritarchs in the Telychian, benthic corals in the Telychian and Wenlock (Kaljo et al. 1995; Kaljo 1996). An analysis performed under the IGCP Project 216 revealed only three fourth-order bioevents (in the early and late Aeronian and early Telychian), where extinctions and radiations of the same groups were closely following but did not affect the group seriously. Most significant seem to be a rather rapid decline in graptolite diversity in the Aeronian and an extinction event at the very end of the Llandovery (Melchin 1994).

The above summary shows that the Llandovery was a special interval in the early Palaeozoic environmental evolution. Below, data on the carbon isotopic composition of the corresponding rocks are added in order to determine how much and in what way changes in $\delta^{13} \mathrm{C}$ values reflect environmental processes. In the interpretation of the carbon isotopic record in the East Baltic sections we try to consider both local and global factors influencing carbon cycling.

\section{GEOLOGICAL SETTING}

Llandovery rocks in the northern part of the East Baltic area (Estonia and Latvia) were formed in a wide gulflike sea on the west margin of the Baltica palaeocontinent (Bassett et al. 1989). Regular associations of sedimentary rocks with specific fossil communities occur as belts subparallel to the shoreline. Nearshore facies are represented by lagoonal dolomites and/or dolomitic marls, in the high-energy shoal belt predominantly grainstones occur, often with organic buildups. In the shallow shelf or mid-shelf area are present different limestones (wackestones with grain- and packstone intercalations) that are locally nodular or micritic and interbedded with marlstones. Seawards, on the deeper outer shelf, mainly marlstones and mudstones, sometimes also micritic limestones occur, forming a transition from shelf to the shelf depression and basin, where dark or even black shales and claystones with graptolites dominate. Basinal (and shelf depression) rocks are rich in pyrite and organic carbon, indicating relatively deep-water, oxygen-deficient depositional conditions.

The sequence of rocks described above marks a transition from shallow to deep sea and shows a clear pattern wheré the terrigenous siliciclastic component (clay and fine silt) in rocks increases and the carbonate content decreases. In grainstones and biohermal limestones the calcite content exceeds $90 \%$ and in 
some micritic limestones is close to $90 \%$, but in skeletal wackestones it falls below $75 \%$ and in deep shelf mudstones is only 10-20\%.

During the Llandovery these main facies belts were shifted in response to sea level changes - some of which might be of eustatic origin. Late Rhuddanian (= lower part of the Raikküla Stage) facies distribution and location of the six cores studied for carbon isotopes are shown in Fig. 1. Most of the cores are located in a relatively deeper water facies with a decreased carbonate content, but they were chosen in order to avoid gaps in the sequence occurring rather often in the shallow shelf area. Nevertheless, as seen from the Ruhnu core, due to different geological reasons hiatuses should be considered also in the deep shelf area.

The stratigraphical terminology employed in the paper is summarized in Fig. 2. For better orientation also generalized graptolite zones (Koren et al. 1996) and absolute ages (modified after Tucker \& McKerrow 1995, see Kaljo et al. 1998) are included. Information on lithologies of the units identified in cores is shown in Fig. 3.
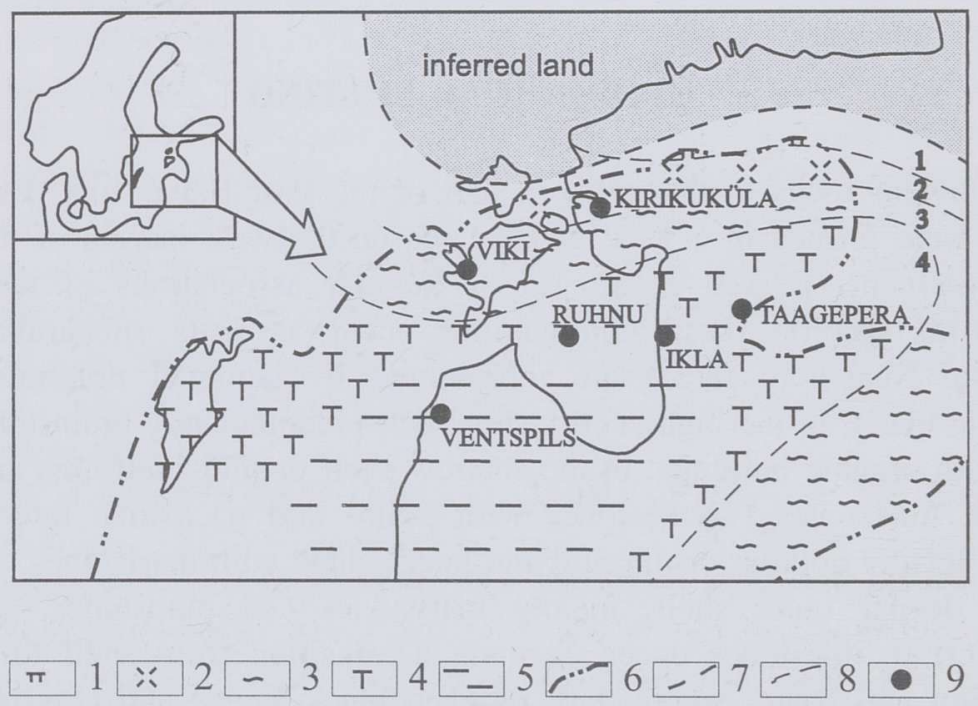

Fig. 1. Location of the studied cores and distribution of early Llandovery (Rhuddanian) rocks and facies belts across the northern Baltic region during the Coronograptus cyphus Chron (after Bassett et al. 1989, simplified). Key: 1, dolomites; 2, skeletal grainstones; 3, skeletal pack- and wackestones; 4, marlstones; 5 , red and green marl- and mudstones; 6 , eroded margin of the Rhuddanian; 7, palaeoshoreline; 8 , facies boundary; 9 , borehole. Numbers on the map mark facies belts: 1 , inshore lagoons and tidal flats; 2 , nearshore high-energy shoals; 3 , shallow mid-shelf; 4, deeper outer shelf. 


\begin{tabular}{|c|c|c|c|c|c|c|c|}
\hline \multirow{2}{*}{$\cdot \frac{\mathscr{s}}{\omega}$} & \multirow{2}{*}{ 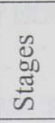 } & \multirow{2}{*}{ 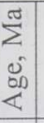 } & \multirow{2}{*}{$\begin{array}{l}\text { Generalized } \\
\text { graptolite zones }\end{array}$} & \multirow{2}{*}{$\begin{array}{l}\text { East } \\
\text { Baltic } \\
\text { stages }\end{array}$} & $\begin{array}{l}\text { Central \& } \\
\text { West Estonia }\end{array}$ & South Estonia & West Latvia \\
\hline & & & & & \multicolumn{3}{|c|}{ Formations, beds } \\
\hline \multirow{2}{*}{$\frac{\vec{z}}{3}$} & \multirow{2}{*}{ 这 } & & $\begin{array}{l}\text { M. belophorus - } \\
\text { M. riccartonensis }\end{array}$ & \multirow{2}{*}{ Jaani } & \multirow{2}{*}{$\begin{array}{l}\text { Jaani } \\
\text { (W) }\end{array}$} & \multirow{2}{*}{$\begin{array}{l}\text { Riga } \\
\text { (W) }\end{array}$} & \multirow{2}{*}{ Riga } \\
\hline & & & $\begin{array}{l}\text { C. murchisoni- } \\
\text { C. centrifugus }\end{array}$ & & & & \\
\hline \multirow{10}{*}{ 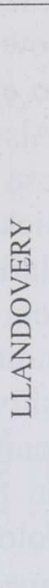 } & \multirow{3}{*}{ 胥 } & & $\begin{array}{l}\text { C. insectus - } \\
\text { O. spiralis }\end{array}$ & \multirow{4}{*}{ Adavere } & \multirow{3}{*}{$\begin{array}{c}\text { Velise } \\
\text { (V) }\end{array}$} & \multirow{3}{*}{ Velise } & \multirow{3}{*}{ Jurmala } \\
\hline & & & $\begin{array}{l}\text { Mcl. crenulata - } \\
\text { Mcl. griestoniensis }\end{array}$ & & & & \\
\hline & & & $\begin{array}{l}\text { Str. crispus - } \\
\text { Spir. guerichi }\end{array}$ & & & & \\
\hline & \multirow{4}{*}{. } & & St. sedgwickii & & Rumba (R) & Rumba & \multirow{4}{*}{ Dobele } \\
\hline & & & D. convolutus & \multirow{4}{*}{ Raikküla } & \multirow{4}{*}{ 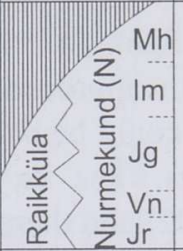 } & \multirow{4}{*}{ Saarde $\mathrm{lk}$} & \\
\hline & & & M. argenteus & & & & \\
\hline & & & $\begin{array}{l}\text { D. pectinatus - } \\
\text { D. triangulatus }\end{array}$ & & & & \\
\hline & . & 43 & Cor. cyphus & & & & \\
\hline & ]ี & & Cys. vesiculosus & & Tamsalu (T) & Õhne & Remte \\
\hline & Е & $442+29$ & Par. acuminatus & Juuru & $\begin{array}{c}\text { Varbola } \\
\text { (Vr) }\end{array}$ & (Ō) & Stačiunai \\
\hline$\stackrel{0}{0}$ & $\dot{E}$ & & N. persculptus & Porkuni & Hiatus & Saldus & Saldus \\
\hline 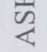 & $\equiv$ & & N. extraordinarius & & Ärina & Kuldiga & Kuldiga \\
\hline
\end{tabular}

Fig. 2. Stratigraphy and correlation of Llandovery rocks of Estonia and West Latvia (mainly after Nestor 1997). Graptolite zones after Koren et al. (1996, simplified), absolute ages from Kaljo et al. (1998). Abbreviations: WENL., Wenlock; ASHG., Ashgill; Sheinw., Sheinwoodian; Hirn., Hirnantian. Beds: Mh, Mõhküla; Im, Imavere; Jg, Jõgeva; Vn, Vändra; Jr, Järva-Jaani. Members: St, Staicele; Le, Lemme; Ik, Ikla; Ko, Kolka; Sl, Slitere.

\section{MATERIAL AND METHODS}

We studied stable isotopes in sections of six boreholes located in the western part of Estonia and in Latvia (Fig. 1). Four of them (Kirikuküla, Ikla, Ruhnu, and Ventspils; three first see Fig. 3, the last is discussed in Kaljo et al. 1998) pass through the entire Llandovery, but the Taagepera and Viki boreholes, respectively, penetrate only the lower and the upper part of it. In all cases also over- and underlying strata (if represented) were analysed in order to tie the $\delta^{13} \mathrm{C}$ curve with well-known Hirnantian and early Wenlock carbon isotopic excursions. The sampling interval was more or less regular depending on the thickness of Llandovery rocks in the particular core, but at boundaries and other specific levels samples were taken more closely. For example, in the Kirikuküla core where the thickness of the Llandovery is $106 \mathrm{~m}, 83$ samples were taken, i.e. the mean sampling interval was $1.3 \mathrm{~m}$; at Ikla (thickness $240 \mathrm{~m}$, 96 samples) the 
interval was $2.5 \mathrm{~m}$. All together isotopes were analysed from about 400 bulk rock samples.

Main attention was paid to the carbon isotope record, since we considered oxygen data unreliable due to difficulties connected with the bulk rock method of isotope analysis. The methodological aspects have been explained in detail earlier (Kaljo et al. 1997, 1998); here we repeat only a few general statements. Previous studies (Brenchley et al. 1994; Kaljo et al. 1997; Heath et al. 1998) show little diagenetic alteration of Baltic early Palaeozoic rocks, which allows us to expect rather good results of carbon isotope analysis also in bulk rock samples. Also, the comparison of our whole rock isotopic data (Kaljo et al. 1998) with those from brachiopod shells of the Gotland Silurian (Wenzel \& Joachimski 1996; Bickert et al. 1997) shows only slight difference in $\delta^{13} \mathrm{C}$ values, but great similarity of curves produced by both approaches. The main advantage of the whole rock method is that sampling could be performed at regular intervals not depending on occurrences of bioclasts. The oxygen isotope ratios are more sensitive to diagenesis (Marshall 1992) and therefore data from whole rock analysis cannot be sufficiently trustworthy. Another difficulty arises from the fact that Baltic carbonate rocks are mostly highly variable mixtures of calcite and dolomite, which have clearly different oxygen isotope fractionation factors. Some idea about oxygen trends based on calcite from brachiopod shells might be obtained from the Ruhnu core data published by Heath et al. (1998). These data will be commented on below.

\section{CARBON ISOTOPE RECORD}

The six core sections studied were correlated by different litho-, cyclo-, and biostratigraphical data; in some cases also the carbon isotopic trend was considered. Due to the geological and facies history the sections were more or less incomplete and represented by various rocks, but together they gave a rather full record of carbon isotope excursions in the Llandovery. Carbon isotope trends from three most complete core sections are demonstrated in Fig. 3. Besides the Llandovery data, also the end-Ordovician and early Wenlock excursions are included for comparison.

The Hirnantian isotopic situation is a starting-point for understanding the Silurian history of carbon cycling. The corresponding $\delta^{13} \mathrm{C}$ values reach $+4.8 \%$ at Kirikuküla (Ärina Formation), $+4.1 \%$ at Taagepera, and $+6.0 \%$ at Ruhnu (both the Kuldiga Formation). At Ikla the maximum value is only $+3.2 \%$, but the section is incomplete and probably only the Saldus part of the Porkuni Stage (Fig. 2) was analysed, which usually shows the values lower than Kuldiga ones. This global isotopic event has been widely discussed in literature; the East Baltic data can be found in papers by Brenchley et al. (1994), Marshall et al. (1997), Kaljo et al. (in press). 

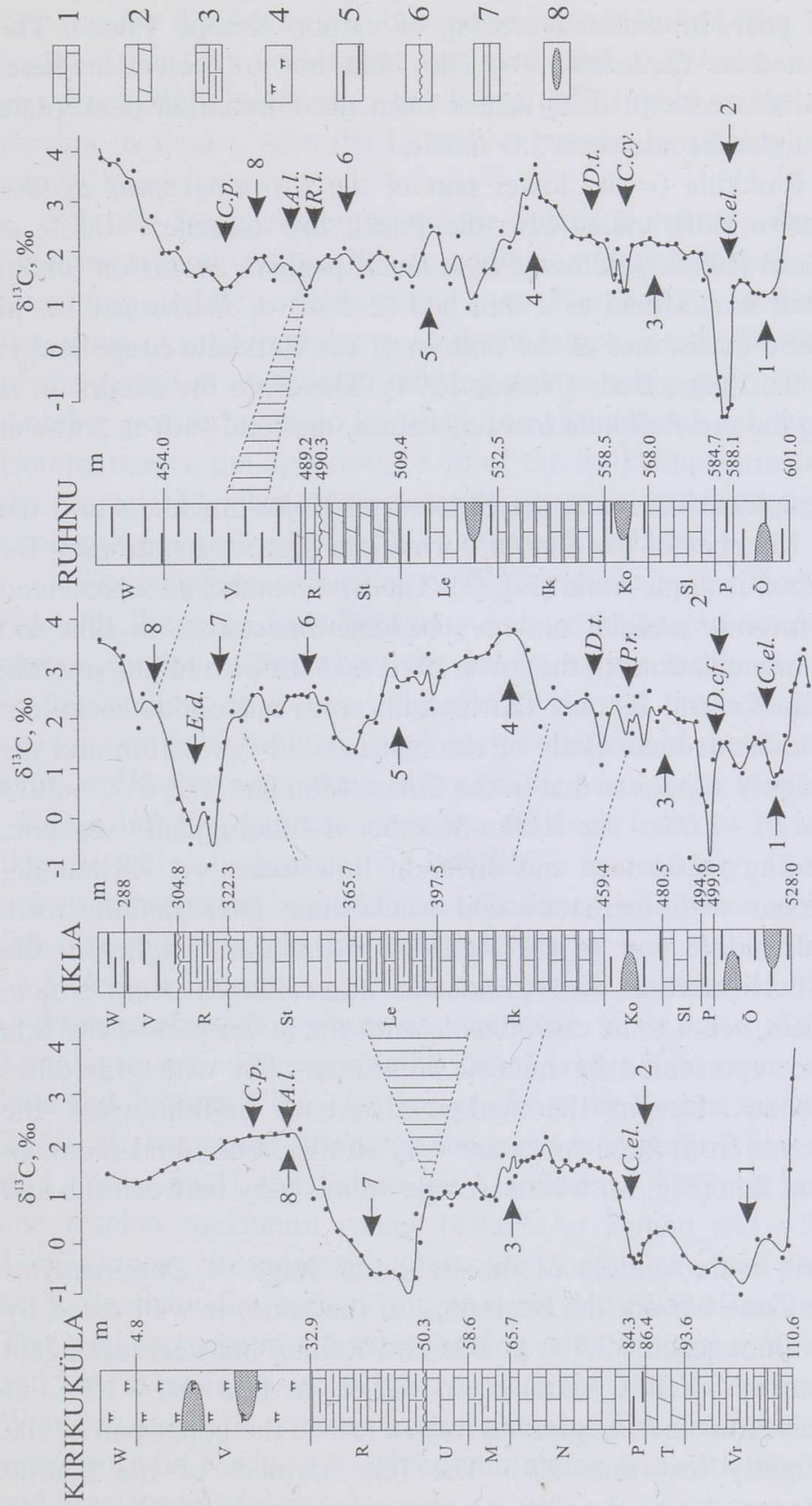

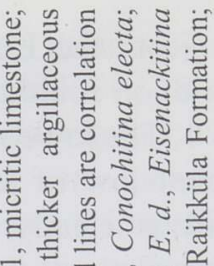
तों

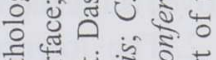

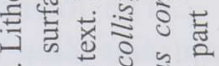

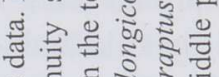

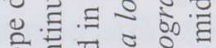

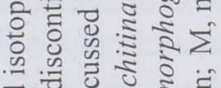
चี त ㅇ स है चٓ

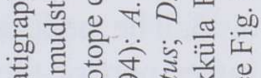

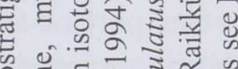

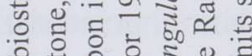

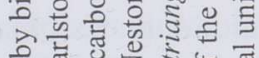
를 的志 ठै ठै

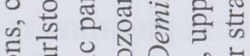
ป气 फ. के टिं

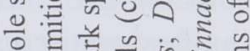

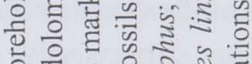

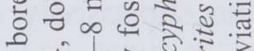
ज仿 ปี I

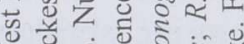

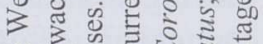
\&

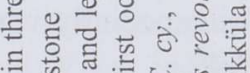

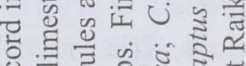
ठ․ㄹ บै क \& टी

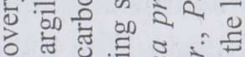

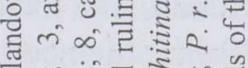

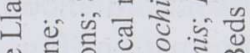

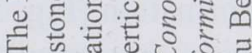
m

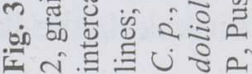


From the Llandovery the following specific intervals of the $\delta^{13} \mathrm{C}$ temporal variation could be listed (Fig. 3):

1. The lowermost Juuru (= probably the Parakidograptus acuminatus graptolite Zone) low or end of post-Hirnantian lessening of carbon isotope values. The shift is clearly indicated at Kirikuküla $(-1.2 \%)$, but not so well elsewhere. Nevertheless, the total decrease in $\delta^{13} \mathrm{C}$ values from the Hirnantian peak (data above) until the level under discussion is 5.0-6.0\%.

2. The lowermost Raikküla (= the lower part of the Coronograptus cyphus graptolite Zone) negative shift, called also the Pusku low (reaches $-0.5 \%$ at Kirikuküla and $-1.2 \%$ at Ruhnu), followed by a small positive excursion (about $2 \%$ ). The negative shift is confined to a thin bed $(2-5 \mathrm{~m})$ of marlstones or, in some cores, to dolomitic marlstones at the bottom of the Raikküla Stage and is called conventionally the Pusku Beds (Nestor 1994). Therefore the excursion is sharp and, considering the pre-Raikküla level of values, the total shift is $2.5 \%$ at Ikla and Ruhnu.

3. The next stratigraphical intervals, the Slitere and Kolka members and the lower part of the Ikla Member of the Saarde Formation, deserve mentioning for their characteristic carbon isotopic trend (Fig. 3). The first member is represented in South Estonia by micritic nodular or wavy bedded limestones (at Ikla and Taagepera with marly intercalations in the lower part) and shows a rather smooth, slightly rising curve. In Central Estonia (Kirikuküla core) analogous rocks are known from the coeval Järva-Jaani Beds of the Nurmekund Formation and the isotopic trend is also highly similar to that in the Slitere Member. The $\delta^{13} \mathrm{C}$ values are in both cases close to $+2.0 \%$. The Kolka Member is lithologically variable, consisting of interbedding marlstones and different limestones. At Kirikuküla, shallow-water grainstones with marlstone and wackestone intercalations form the supposedly coeval middle part of the Raikküla Formation. Higher in the Kirikuküla core micritic limestones with grainstone intercalations occur which, according to isotope data, seem to be correlatable with the lower part of the Ikla Member which is also represented by micritic limestones but with graptolitebearing argillaceous bands. Despite the marked difference in lithologies, the changes in isotopic curves from these rocks are very similar. The trend seems to be especially variable at Ikla (Fig. 3), where isotope values vary between 0.8 and $2.4 \%$.

4. The positive shift in the middle of the Raikküla Stage (= Demirastrites triangulatus graptolite Zone but not the beginning of the zone) is well dated by graptolites. The $\delta^{13} \mathrm{C}$ values reach $+3.7 \%$ at Ikla and Ruhnu, but decrease again towards the upper limit of the Ikla Member, to $+2.1 \%$ at Ikla and $+1.6 \%$ at Ruhnu. The total increase in values, beginning from a low in the upper part of the Kolka Member, is slightly less than 3\%o. The Ikla Member of the Saarde Formation (Fig. 2) accommodating the shift is represented by micritic limestones with thin argillaceous interbeds containing abundant graptolite remains. At Kirikuküla the Ikla peak is missing due to a hiatus in the sequence. 
5. The Lemme Member of the Saarde Formation demonstrates an analogous pattern to the Ikla Member excursion of $\delta^{13} \mathrm{C}$ values with a low peak $(+3.2 \%$ at Ikla) in the middle of the member followed by a decrease in values to $+1.3 \%$. The trend is distinct at Ikla, but not so clear at Ruhnu (Fig. 3). The corresponding rocks of the Lemme Member are mud- and marlstones with micritic limestone and wackestone nodules in the lower part; higher in the section the carbonate content increases. Also the Lemme excursion is missing at Kirikukuila due to a gap in the section.

6. In the Staicele Member of the Saarde Formation the $\delta^{13} \mathrm{C}$ values increase again to around $2 \%$ (at Ikla just above and at Ruhnu just below 2\%o, Fig. 3), remaining slightly variable at this level. The Staicele Member consists of micritic limestones, partly nodular or with mudstone interbeds. At Kirikuküla this part of the record is considered missing due to a big gap in the shallow shelf area. Another possibility is to correlate, on the grounds of the similarity of carbon isotope trends, the uppermost $8 \mathrm{~m}$ of the Raikküla Formation with some part of the Staicele Member. Unfortunately, there is no biostratigraphic data available confirming or contradicting this tentative correlation.

7. The negative excursion of $\delta^{13} \mathrm{C}$ values in the Rumba Formation of the Adavere Stage (= Stimulograptus sedgwickii graptolite Zone) is a remarkable carbon isotope event, where the lowest values reach $-1.3 \%$ at Kirikuküla and $-0.9 \%$ at Ikla. At Ruhnu only a small part of the beds is represented (Fig. 3), showing probably only the beginning or the end of the shift. At Viki the negative shift is clearly pronounced although the values are modest - the minimum is $+0.1 \%$, but the decrease from the previous level is $1.4 \%$. At Kirikuküla and Ikla the latter numbers are 2.3 and 3.0\%o, respectively. The Rumba Formation is mainly represented by nodular wackestones with more argillaceous interbeds; at Ikla also some micritic limestone beds occur.

8. A small positive shift occurs in the bottom of the Velise Formation (= Pterospathodus eopennatus conodont Zone, and Spirograptus guerichiStreptograptus crispus graptolite Zone), where $\delta^{13} \mathrm{C}$ values reach $2.3 \%$ at Kirikuküla and $2.7 \%$ at Viki. The increase from the Rumba low is respectively 3.6 and $2.6 \%$. Higher in the formation the trend is slightly falling (to $0.7 \%$ at Ikla and to $1.1 \%$ at $\mathrm{Viki}$ ), but before the Llandovery-Wenlock boundary it rises again and reaches maximum values $(+4.6 \%$ at Ruhnu and $+5.2 \%$ at Viki) in the Monograptus riccartonensis graptolite Zone. The latter peak is the well-known early Sheinwoodian carbon isotope event described elsewhere (Kaljo et al. 1998). The total increase in values beginning from the upper Velise low in the Ruhnu and Viki cores is 3.3 and $4.1 \%$, respectively. The Velise Formation and the lower Wenlock are both represented by rather argillaceous rocks, mainly mudstones, sometimes (at Kirikuküla) slightly dolomitic and with more calcareous interbeds and limestone nodules.

The rocks of the Ventspils core are the deepest-water ones among those studied (Fig. 1). Due to high condensation of the main part of the Llandovery in 
the section, we considered our sampling insufficient and therefore the data obtained were not included into the detailed record above. The Rhuddanian part of the core is $15 \mathrm{~m}$ thick and is represented by interbedding of marlstones and micritic limestones. The $\delta^{13} \mathrm{C}$ values vary between -0.2 and $+1.2 \%$, but the number of measurements is too limited to allow correct correlation. The Aeronian Stage is represented in the core by black shales of the Dobele Formation (11 m, Fig. 2). Three consecutive samples from its top part show the values of $-1.1,+0.3$, and $-1.4 \%$. The first two are dated by graptolites (Gailite et al. 1987) as belonging to the Demirastrites convolutus Zone and the highest one as to the Stimulograptus sedgwickii Zone. Thus, the Rumba negative excursion described above is supported also by Ventspils data, but these may refer to a wider time interval involved. The Telychian part of the section is not that condensed and the data are easier to interpret. A low peak $(+1.6 \%)$ in the middle of the Jurmala Formation (= Str. crispus graptolite Zone) could be correlated with an analogous positive shift in the Velise Formation. At the very top of the Jurmala Formation, just before the positive shift begins, a value of $-1.0 \%$ o is measured. The maximum $\delta^{13} \mathrm{C}$ values $(+3.8 \%$ ) are recorded from the M. riccartonensis Zone in the Riga Formation. The total increase in values is correspondingly $4.8 \%$.

\section{DISCUSSION AND ENVIRONMENTAL INTERPRETATION}

The detailed record of carbon isotope data presented above allows us to distinguish some characteristic patterns of carbon cycling in the Llandovery. In looking for the most general tendencies of changes in $\delta^{13} \mathrm{C}$ values, two different approaches seem possible. According to one model, four main episodes of changes can be identified between the Hirnantian and early Wenlock peaks, two with a dominantly falling trend and the other two with a rising trend as follows.

The first episode is defined as a decline in $\delta^{13} \mathrm{C}$ values from the Hirnantian peak $(6.0 \%$ at Ruhnu) through a relative stabilization interval in the early Rhuddanian (values vary between -1.2 and $+1.5 \%$ ) until minimum values $(-1.2 \%$ at Ruhnu) in the lower part of the C. cyphus Zone were reached. The total decline in values was $7 \%$. The whole episode took c. $5 \mathrm{Ma}$ but most of the time (at least $4 \mathrm{Ma}$ ) was occupied by the stabilization interval. Both negative shifts were very brief events $-0.5 \mathrm{Ma}$ or less, especially in the case of the Pusku low.

The second episode represents a rising trend. It began with a rapid recovery from the above minimum, followed by an interval of variable $\delta^{13} \mathrm{C}$ values $(0.8-$ $2.4 \%$ at Ikla) and a later increase in values until a peak $(3.7 \%$ ) in the middle of the D. triangulatus Zone. The total increase in values was about 5\%o. This episode was much shorter, only 1.5 graptolite zones, i.e. less than $2 \mathrm{Ma}$, including two brief positive shifts. 
The third main episode is a complicated decline in $\delta^{13} \mathrm{C}$ values beginning with the Ikla peak and continuing through a rather variable interval (values between 1.0 and $2.5 \%$ in the Lemme and Staicele members) until the Rumba minimum $(-1.3 \%$ at Kirikuküla) in the St. sedgwickii Zone. The total decrease was c. $5 \%$. This episode corresponds nearly to the whole Aeronian. Probably these changes lasted c. $3 \mathrm{Ma}$, whereas most of this time was occupied by the intermediate variable interval.

The last episode in Llandovery carbon cycling shows an increase in $\delta^{13} \mathrm{C}$ values, beginning with the Rumba low and reaching the peak (5.2\%o at Viki) in the early Wenlock. The Kirikuküla and Ruhnu cores show also an intermediate interval with a variable isotope content $(1.2-2.7 \%$ ). This interval corresponds nearly to the whole Telychian (4 Ma) minus the beginning of the positive shift which commenced just before the Llandovery-Wenlock junction. The total increase in values during the episode was $6.5 \%$, divided between two nearly equal steps.

Another possibility of classifying the general carbon isotope changes is to bring forward three different types of the trend - conspicuous positive and negative excursions and intermediate intervals of variable $\delta^{13} \mathrm{C}$ values. In the above detailed record the following four main short-lived excursions were listed: (1) the Pusku low in the C. cyphus Zone (2 in Fig. 3, approximate age $438 \mathrm{Ma}$ ); (2) the Ikla peak in the D. triangulatus Zone (4 in Fig. 3, c. $436 \mathrm{Ma}$ ); (3) the Rumba low in the St. sedgwickii Zone (7 in Fig. 3, c. $433 \mathrm{Ma}$ ); (4) the endLlandovery positive shift in the Cyrtograptus insectus-Oktavites spiralis Zone (Fig. 3, c. $429 \mathrm{Ma}$; peak values were reached later in the Wenlock). Before and after these excursions the carbon isotope curve is variable (mainly around $1.0-2.0 \%$ ) without any clear tendency toward rising or falling during an episode (some decline in values in the Aeronian at Ikla is not supported by data from the Ruhnu core, Fig. 3).

Further analysis should show which of the two above models of carbon cycling fits better with other environmental data, but we prefer the latter one telling that the background carbon isotope values were relatively stable through the entire Llandovery. Mean values by the intermediate intervals calculated from the Ikla and Ruhnu data show the lowest values in the post-Hirnantian Juuru Stage $(1.3 \%$ ) , a clear increase in the upper Rhuddanian (lower Raikküla Stage, $1.9 \%$ ), and nearly stable mean values in the Aeronian and Telychian (c. $2.0 \%$ ). The Kirikuküla core, which is located more onshore, shows lower mean values, but the tendency is the same. The above smooth trend was interrupted only by four rather brief events (two negative and two positive excursions) which occupied just a small fraction of time. Below we try to clarify which of the known environmental events might be responsible for these isotopic shifts.

The oxygen isotope curve published by Heath et al. (1998) shows only a very gradual change toward more negative $\delta^{18} \mathrm{O}$ values throughout the Llandovery, i.e. from $-4.2 \%$ as mean at the bottom to $-5.3 \%$ at the top, indicating a slow rise of 
temperature. The character of the trend is in harmony with ideas about the early Silurian climate (see above) and carbon isotope curve with the exception of three short-lived events described above (the Hirnantian and early Wenlock positive $\delta^{13} \mathrm{C}$ excursions are well seen in the $\delta^{18} \mathrm{O}$ curve). The noted discrepancy with our carbon data in the Llandovery seems to be caused by gaps in the brachiopod sampling record.

Three glaciation episodes accompanied by glacio-eustatic lowstands have been established in the Llandovery of Brazil (Caputo 1998). Assuming that dating of the Brazilian glaciations in terms of graptolite zonation is sufficiently exact (see also two paragraphs further), we can correlate the East Baltic events with South American ones with the precision of a graptolite zone. Accordingly, we can believe that the Ikla positive excursion is synchronous with the glaciation in the early Aeronian (Coronograptus gregarius graptolite Zone, Caputo 1998), and the Rumba negative excursion with the beginning of the second glaciation dated by Caputo (1998) from late Aeronian to early Telychian. The third glaciation at the Llandovery-Wenlock junction corresponds to the early Wenlock positive peak beyond our timeframe but starting in the topmost Velise beds (Fig. 3).

Comparison with well-studied Hirnantian glaciation (op. cit. above) shows that the Ikla and early Wenlock positive excursions fit well into the glaciation pattern (positive shift, sea level lowering, extinction of biota, etc.; see Marshall \& Brenchley 1998), but the Rumba negative shift is a contradiction. From our point of view, problems of dating should be considered here. Discussing Ventspils data, we noted above that the Rumba negative excursion might occupy a wider time span, i.e. to begin earlier, perhaps in the $D$. convolutus Zone. If this is true, then the Rumba isotopic low corresponds to a sea level minimum (compared with the Panuara hiatus as mentioned above), which might be glacio-eustatic but, according to recent datings (Caputo 1998), is not. However, the Ventspils data are preliminary and need to be checked. The Rumba Formation, marking a new transgression, apparently corresponds only to the upper part of the St. sedgwickii Zone (Fig. 2). Here we should note that the Aeronian, especially late Aeronian, was a complicated time in the Baltic-Scandinavian facies evolution. For example, in the Ohesaare core a major hiatus embraces the interval from the middle of the D. triangulatus Zone until the middle of the Spirograptus turriculatus Zone (Loydell et al. 1998). The rocks from the gap interval are partly represented in other cores, but the widest gap in the East Baltic occurs on the D. convolutus Zone level which in Scandinavia and also in the Central East Baltic marks a deepening event with a wide distribution of anoxic conditions (true black shales), followed by a regression in the St. sedgwickii Zone (grey shales, Bassett et al. 1989). From this comment it is clear that the construction of a sea level curve might sometimes depend considerably not only on global but also on local or regional factors (e.g. tectonics).

On the other hand, Loydell (1994) has shown that a glaciation and related sea level fall occurred at the very beginning of the Telychian. This suggests that the 
maximum of the second Silurian glaciation was probably in the early Telychian rather than in the late Aeronian. The same could be concluded from the distribution of some early Telychian chitinozoans in the shales occurring lateral to the tillites in Brazil (Caputo 1998). Proceeding from this age determination, we can consider the small positive peak ( 8 in Fig. 3 ) immediately higher of the Rumba low as a reflection of the glaciation. In this context, but also considering other glaciations mentioned, we agree with the idea of Heath et al. (1998) that smaller isotope shifts are associated with less pronounced environmental events. If the above discussion is correct, then there seem to be grounds for thinking that the glaciation model works well in the interpretation of the Llandovery positive excursions listed.

The negative excursions were established in different positions with regard to the glaciations noted above and in different lithologies. The Pusku low occurs in mudstones long away from both preceding and following glacial events. The Rumba low occurs in wackestones and perhaps close to the next glacial event (see previous paragraph). These lows mark more or less remarkable transgression events in the sections. In the Pusku case the preceding regression in late Juuru time was relatively modest, but the Rumba sea level rise followed a deep lowstand accompanied by regional gaps in the Baltic basin and elsewhere. However, sea level alone seems insufficient to explain a prominent carbon isotope anomaly. Checking with biotic events is not very promising, because in the Llandovery most of the biotic groups were recovering from a serious extinction in the latest Ordovician. The Rhuddanian was in general a lowdiversity and perhaps also a low-productivity period, but too long to produce a brief shift. Planktic graptolites had a diversity burst in the early Aeronian, which was followed by stepped extinction and reduction of diversity until the late Aeronian (Kaljo et al. 1995). This bioevent might have contributed to the Rumba negative shift, analogously to that reported by Magaritz (1989) for the PermianTriassic boundary. Nevertheless, it alone seems insufficient for explanation of the excursion, especially when bioproductivity, the main agent in removal of organic carbon from the surface layer of the ocean, and biodiversity are not strictly related phenomena.

Modifying Jeppsson's (1990) model of oceanic episodes, Bickert et al. (1997) associate low $\delta^{13} \mathrm{C}$ values with humid climatic conditions at low latitudes, which cause intense weathering and prevailing sedimentation of terrigenous-calcareous muds (marlstones and argillaceous limestones). In spite of some problems with this model, the general idea of the connection of carbon cycling with the climatic situation is undoubtedly productive and can be used for explanation of the negative excursions discussed above. The lithology of the Pusku Beds and Rumba Formation and sea level rise in both times favour the humid state model by Bickert et al. (1997), but wider distribution of black shales on the shelf, predicted by the model, does not fit into the real facies situation. Moreover, black shales as sinks for burial of light carbon would cause an increase in $\delta^{13} \mathrm{C}$ values, but this is not the case. 
In discussing the possible causes of the Rumba carbon isotope low, effects of the influx of volcanic $\mathrm{CO}_{2}$ or even methane from gas hydrates (Weissert 2000) into ocean waters should be considered. Volcanic activities were rather frequent in the Iapetus region during the Llandovery. Bergström et al. (1992) listed over 30 individual beds of K-bentonites from Baltoscandia, but usually only millimetre scale beds were produced. The most prominent bed occurs in the lower part of the Rumba Formation and contemporary ashbeds are traced over a wide area in North Europe. These beds mark a serious volcanic eruption, which might release a sufficient quantity of $\mathrm{CO}_{2}$ with low $\delta^{13} \mathrm{C}($ c. $-7 \%$ ) and thus give rise to the Rumba $\delta^{13} \mathrm{C}$ negative shift. Unfortunately data about this eruption are inadequate for any mass calculations and therefore the above idea is mentioned only as a possibility.

The influence of the climatic and facies situation on the carbon isotope composition of rocks could further be demonstrated by the striking harmony between the general pattern of the carbon isotope curve and subdivisions of the East Baltic Llandovery (Fig. 3). This accordance points to certain environmental reasons reflected in stratigraphy, but surely more investigations are needed to elaborate a model logical in every respect. At this stage, and excluding from the discussion the intervals correlated above with the Brazilian glaciations (the middle part of the Ikla Member and the lower part of the Velise Formation), we note here only a few regularities. One of these is the connection of positive excursions or elevated intervals of the carbon isotope curve with units (e.g. Tamsalu Formation; Slitere, Ikla, and Staicele members of the Saarde Formation) represented by carbonate rocks with a low content of terrigenous material (Fig. $3)$. As to the environmental conditions under which such limestones are formed, we can mention relatively warm climate and shallow warm sea without notable terrigenous influx but often with organic buildups. In sections such pure carbonates mark shallowing of the sea, even if some of these limestones may occur in the relatively deeper part of the shelf. Bickert et al. (1997) termed these conditions as the arid state, Jeppsson (1990) as the Secundo Episode, but differently from the former authors he assigned low $\delta^{13} \mathrm{C}$ values to this episode.

Carbon isotope trends derived from sections of different facies origin (Figs. 1 and 3) show that the upper Juuru (Tamsalu Formation in the Kirikuküla core) positive excursion is clearly recognizable also in the Ikla and Ruhnu sections in the Õhne Formation, represented by much more argillaceous rocks. This observation proves that the shape of the curve does not depend on lithology but on more general climatic and oceanic conditions. Consequently, the intervals of the curve representing the units made up of lithological intercalations (Kolka and Lemme members, Fig. 3) reflect rather unstable environmental conditions. However, here it should be noted that there may be too many different reasons (including diagenesis) for about $1 \%$ changes in $\delta^{13} \mathrm{C}$ values and these cannot be taken seriously. Also, data from one or a few sections without a wider facies background of a basin cannot give a reliable basis for understanding changes in geological history. 


\section{CONCLUSIONS}

1. Four relatively important carbon isotopic events were established in the East Baltic Llandovery: positive excursions in the Ikla Member and Velise Formation, and negative shifts in the Pusku Beds and Rumba Formation. The positive excursions seem to reflect corresponding glaciations, negative ones humid climatic episodes with rising sea level; in case of the Rumba Formation also the influence of light carbon released due to volcanic activity in the late Aeronian is suggested.

2. The background carbon isotope values were rather stable during the Llandovery, except the earliest Rhuddanian, which showed a post-Hirnantian relative lowstand. A good harmony between the general shape of the isotope trend and environmentally controlled stratigraphical units was observed.

\section{ACKNOWLEDGEMENTS}

We are grateful to our colleagues who helped us at different stages of fieldwork and to J. Nemliher for technical assistance. J. D. Marshall and R. Vaikmäe are thanked for constructive reviews of the paper. The Geological Surveys of Estonia and Latvia are acknowledged for permission to study and take samples from the borehole cores discussed in the paper. This study was financially supported by the Estonian Science Foundation (grant No. 3751).

\section{REFERENCES}

Bassett, M. G., Kaljo, D. \& Teller, L. 1989. The Baltic region. In A Global Standard for the Silurian System (Holland, C. H. \& Bassett, M. G., eds.). Nat. Mus. Wales Geol. Ser., 9, $158-170$.

Bergström, S. M., Huff, W. D., Kolata, D. R. \& Kaljo, D. 1992. Silurian K-bentonites in the Iapetus Region: a preliminary event-stratigraphic and tectonomagmatic assessment. Geol. Fören. Stockh. Förhandl., 114, 327-334.

Bickert, T., Pätzold, J., Samtleben, C. \& Munnecke, A. 1997. Paleoenvironmental changes in the Silurian indicated by stable isotopes in brachiopod shells from Gotland, Sweden. Geochim. Cosmochim. Acta, 61, 2717-2730.

Brenchley, P. J., Marshall, J. D., Carden, G. A. F., Robertson, D. B. R., Long, D. F. G., Meidla, T., Hints, L. \& Anderson, T. F. 1994. Bathymetric and isotopic evidence for a short-lived Late Ordovician glaciation in a greenhouse period. Geology, 22, 295-298.

Caputo, M. V. 1998. Ordovician-Silurian glaciations and global sea-level changes. In Silurian Cycles. Linkages of Dynamic Stratigraphy with Atmospheric, Oceanic, and Tectonic Changes (Landing, E. \& Johnson, M. E, eds.). New York State Mus. Bull., 491, 15-25.

Fischer, A. G. 1984. The two Phanerozoic, supercycles. In Catastrophes and Earth History (Berggren, W. A. \& Van Couvering, J. A., eds.), pp. 129-150. Princeton Univ. Press.

Frakes, L. A. 1979. Climates Throughout Geologic Time. Elsevier, Amsterdam.

Gailite, L. K., Ulst, R. Z. \& Yakovleva, V. I. 1987. Stratotipicheskie i tipovye razrezy Latvii. Zinatne, Riga (in Russian). 
Heath, R. J., Brenchley, P. J. \& Marshall, J. D. 1998. Early Silurian carbon and oxygen stableisotope stratigraphy of Estonia: implications for climate change. In Silurian Cycles. Linkages of Dynamic Stratigraphy with Atmospheric, Oceanic, and Tectonic Changes (Landing, E. \& Johnson, M. E, eds.). New York State Mus. Bull., 491, 313-327.

Jell, J. S. \& Talent, J. A. 1989. Australia: the most instructive sections. In A Global Standard for the Silurian System (Holland, C. H. \& Bassett, M. G., eds.). Nat. Mus. Wales Geol. Ser., 9, 183-200.

Jeppsson, L. 1990. An oceanic model for lithological and faunal changes tested on the Silurian record. J. Geol. Soc. London, 147, 663-674.

Johnson, M. E. 1996. Stable cratonic sequences and a standard for Silurian eustasy. In Paleozoic Sequence Stratigraphy: Views from the North American Craton (Witzke, B. J., Ludvigson, G. A. \& Day, J., eds.). Geol. Soc. Am. Spec. Pap., 306, 203-211.

Kaljo, D. 1996. Diachronous recovery patterns in Early Silurian corals, graptolites and acritarchs. In Biotic Recovery from Mass Extinction Events (Hart, M. B., ed.). Geol. Soc. Spec. Publ., London, 102, 127-133.

Kaljo, D., Boucot, A. J., Corfield, R. M., Koren, T. N., Křiž, J., Le Herisse, A., Männik, P., Märss, T., Nestor, V., Shaver, R. H., Siveter, D. J. \& Viira, V. 1995. Silurian bio-events. In Global Events and Event Stratigraphy in the Phanerozoic (Walliser, O. H., ed.), pp. 173224. Springer, Berlin.

Kaljo, D., Kiipli, T. \& Martma, T. 1997. Carbon isotope event markers through the WenlockPřidoli sequence at Ohesaare (Estonia) and Priekule (Latvia). Palaeogeogr. Palaeoclimatol. Palaeoecol., 132, 211-223.

Kaljo, D., Kiipli, T. \& Martma, T. 1998. Correlation of carbon isotope events and environmental cyclicity in the East Baltic Silurian. In Silurian Cycles. Linkages of Dynamic Stratigraphy with Atmospheric, Oceanic, and Tectonic Changes (Landing, E. \& Johnson, M. E, eds.). New York State Mus. Bull., 491, 297-312.

Kaljo, D., Hints, L., Martma, T. \& Nõlvak, J. 2000. Carbon isotope stratigraphy in the latest Ordovician of Estonia. Chem. Geol. (in press).

Koren, T. N., Lenz, A. C., Loydell, D. K., Melchin, M. J., Štorch, P. \& Teller, L. 1996. Generalized graptolite zonal sequence defining Silurian time intervals for global paleogeographic studies. Lethaia, 29, 59-60.

Kump, L. R., Arthur, M. A., Patzkowsky, M. E., Gibbs, M. T., Pinkus, D. S. \& Sheehan, P. M. 1999. A weathering hypothesis for glaciation at high atmospheric $p \mathrm{CO}_{2}$ during the Late Ordovician. Palaeogeogr. Palaeoclimatol. Palaeoecol., 152, 173-187.

Loydell, D. K. 1994. Early Telychian changes in graptoloid diversity and sea level. Geol. J., 29, 355-368.

Loydell, D. K., Kaljo, D. \& Männik, P. 1998. Integrated biostratigraphy of the lower Silurian of the Ohesaare core, Saaremaa, Estonia. Geol. Mag., 135, 769-783.

Magaritz, M. 1989. ${ }^{13} \mathrm{C}$ minima follow extinction events: a clue to faunal radiation. Geology, 17, 337-340.

Marshall, J. D. 1992. Climatic and oceanographic isotopic signals from the carbonate rock record and their preservation. Geol. Mag., 129, 143-160.

Marshall, J. D. \& Brenchley, P. J. 1998. Oceanic and atmospheric changes at the end of the Ordovician: geochemical enigmas or the end of a beautiful hypothesis? Mineral. Mag., 62A, 951-952.

Marshall, J. D., Brenchley, P. J., Mason, P., Wolff, G. A., Astin, R. A., Hints, L. \& Meidla, T. 1997. Global carbon isotopic events associated with mass extinction and glaciation in the Late Ordovician. Palaeogeogr. Palaeoclimatol. Palaeoecol., 132, 195-210.

Melchin, M. 1994. Graptolite extinction at the Llandovery-Wenlock boundary. Lethaia, 27, 285290.

Morrow, J. R., Schindler, E. \& Walliser, O. H. 1995. Phanerozoic development of selected global environmental features. In Global Events and Event Stratigraphy in the Phanerozoic (Walliser, O. H., ed.), pp. 53-61. Springer, Berlin. 
Nestor, H. 1997. Silurian. In Geology and Mineral Resources of Estonia (Raukas, A. \& Teedumäe, A., eds.), pp. 89-106. Estonian Acad. Publ., Tallinn.

Nestor, V. 1994. Early Silurian Chitinozoans of Estonia and North Latvia. Estonian Acad. Publ., Tallinn.

Torsvik, T. H., Smethurst, M. A., Meert, J. G., Van der Voo, R., McKerrow, W. S., Brasier, M. D., Sturt, B. A. \& Walderhaug, H. J. 1996. Continental break-up and collision in the Neoproterozoic and Palaeozoic - a tale of Baltica and Laurentia. Earth Sci. Rev., 40, 229-258.

Tucker, R. D. \& McKerrow, W. S. 1995. Early Paleozoic chronology: a review in light of new U-Pb zircon ages from Newfoundland and Britain. Can. J. Earth Sci., 32, 368-379.

Weissert, H. 2000. Deciphering methane's fingerprint. Nature, 406, 356-357.

Wenzel, B. \& Joachimski, M. M. 1996. Carbon and oxygen isotopic composition of Silurian brachiopods (Gotland/Sweden): palaeoceanographic implications. Palaeogeogr. Palaeoclimatol. Palaeoecol., 122, 143-166.

Wilde, P., Berry, W. B. N. \& Quinby-Hunt, M. S. 1991. Silurian oceanic and atmospheric circulation and chemistry. In The Murchison Symposium (Bassett, M. G., Lane, P. D. \& Edwards, D., eds.). Spec. Pap. Palaeontol., 44, 123-143.

\title{
SÜSINIKU ISOTOOPIDE SISALDUS BALTI LLANDOVERY (SILUR) KIVIMITES KUI KESKKONNATINGIMUSTE INDIKAATOR
}

\author{
Dimitri KALJO ja Tõnu MARTMA
}

On esitatud andmed kuue uuritud puursüdamiku Llandovery kivimite süsiniku isotoopkoostise kohta. Positiivsed anomaaliad Ikla kihistikus ja Velise kihistiku alguses ning lõpus arvatakse tingitud olevat samaaegsetest glatsiaalsetest sündmustest. Negatiivsed anomaaliad Raikküla lademe Pusku kihtides ja Rumba kihistus seotakse vastavate humiidsete kliimaintervallidega, mida iseloomustab ka ookeani veetaseme tõus. Viimase puhul on võimalik vulkaanilise süsihappegaasi kaasmõju.

\section{СОСТАВ ИЗОТОПОВ УГЛЕРОДА В ПОРОДАХ ПРИБАЛТИЙСКОГО ЛЛАНДОВЕРИ (СИЛУР) КАК ИНДИКАТОР УСЛОВИЙ СРЕДЫ}

\author{
Димитри КАЛЬО и Тыну МАРТМА
}

Сообщаются данные о составе изотопов углерода в разрезах шести буровых скважин, расположенных в Эстонии и в Западной Латвии. Позитивные аномалии, установленные в иклаской пачке райккюлаского горизонта и в низах и верхах велизеской свиты, вероятно, обусловлены гляциальными явлениями. Негативные аномалии в пускуских слоях райккюлаского горизонта и в румбаской свите связываются с гумидными климатическими интервалами, сопровождаемыми повышением уровня океана. В последнем случае возможно влияние вулканического углекислого газа. 